\title{
CONTEMPORARY CHRISTIANITIES IN SOUTHEAST ASIA
}

\section{Challenges and Opportunities}

\author{
Peter C. Phan \\ Georgetown University \\ Peter.C.Phan@georgetown.edu
}

The purpose of this Introduction is to provide the context for the five articles in this issue of the Indonesian Journal of Theology. These articles deal with some aspects of Christianity in five countries in Southeast Asia, namely, Indonesia, the Philippines, Myanmar, Singapore, and Cambodia. Southeast Asia covers $4,500,000 \mathrm{~km}^{2}(1,700,000 \mathrm{sq} \mathrm{mi})$ and has a total population of more than 655 million. It is composed of two subregions. First, mainland Southeast Asia, historically known as Indochina, includes Myanmar, Thailand, Vietnam, Cambodia, and Laos. Second, maritime Southeast Asia, historically referred to as the Malay Archipelago, consists of Malaysia, Singapore, Brunei, Indonesia, the Philippines, and Timor-Leste (East Timor). ${ }^{1}$

The term "Southeast Asia" was not in general use until the Pacific War (1941-1945) when the U.S. and its allies recognized that the region between China and India, which was occupied by the Japanese, was an area of military and economic importance and gave the name "Southeast Asia" to this region of Asia, to distinguish it from East Asia and South Asia. The eleven nationstates currently constituting Southeast Asia are so far-flung geographically and so diverse in history, language, and culture that the value of "Southeast Asia" as a coherent analytical tool has been questioned. ${ }^{2}$ Despite these initial misgivings, programs in Southeast

${ }^{1}$ Note that Malaysia is often listed as belonging to both the first and second subregions, its western part linked with the mainland and its eastern part being an island.

${ }^{2}$ For histories of Southeast Asia as a region, see the four-volume paperback edition of Nicholas Tarling, ed., The Cambridge History of Southeast Asia (Cambridge: Cambridge University Press, 1999) and the three-volume work edited by Ooi Keat Gin, Southeast Asia: A Historical Encyclopedia from Angkor Wat to East Timor (Santa Barbara, CA: ABC Clio, 2004). Good one-volume studies include D. R. SarDesai, Southeast Asia: Past \& Present (Boulder, CO: Westview Press, 1994); Oliver W. Wolters, History, Culture, and Region in Southeast Asian 
Asia as a study area have been established at many universities, and scholarly publications on it are flourishing, focusing on the common aspects of its eleven nation-states and their international, especially economic, relations. ${ }^{3}$ Several organizations were founded with the goal to promote regional collaboration and thus contribute to peace, development, and prosperity in the region. Notable among them are the Southeast Asia Treaty Organization (SEATO), an anti-communist containment pact, founded in 1954 and disbanded in 1977; the Association of Southeast Asia (ASA) in 1961; and the Association of Southeast Asian Nations (ASEAN) in 1967. (Today, of the eleven nation-states making up Southeast Asia only ten are members of ASEAN, with Timor-Leste not being a member.)

Besides the common socio-political, economic, and security concerns that forge various coalitions among the Southeast Asian nation-states, one element that is shared by them is religion. Buddhism, Hinduism, Daoism, Confucianism, Islam, and Christianity, not to mention primal religions, are present in all eleven states, either as a majority or minority religion. All these religions, as Thomas David DuBois has shown, have been a fundamental historical force exercising an exceedingly diverse impact on modern Southeast Asian society. ${ }^{4}$ Here I focus on Christianity. I begin with a brief statistical description of the current condition of the main Christian denominations and movements. I next highlight the common problems facing Christianity in Southeast Asia as a whole. Lastly, I discuss the challenges and opportunities facing Southeast Asian Christianity.

Perspectives (Ithaca, NY: SEAP, 1999); Norman G. Owen, ed., The Emergence of Modern Southeast Asia: A New History (Honolulu, HI: University of Hawai'i Press, 2005); Milton Osborne, Southeast Asia: An Introductory History (Crows Nest, Australia: Allen Unwin, 2016); Milton Osborne, Exploring Southeast Asia: A Traveler's History of the Region (Crows Nest, Australia: Allen \& Unwin, 2002); Robert L. Winzeler, The Peoples of Southeast Asia Today: Ethnography, Ethnology, and Change in a Complex Region (Lanham, MD: Rowman \& Littlefield, 2011). On the challenges of writing Southeast Asian history and the various approaches to it, see the helpful essay by J. D. Legge, "The Writing of Southeast Asian History," in The Cambridge History of Southeast Asia, Volume One: From Early Times to c. 1500, ed., Nicholas Tarling (Cambridge: Cambridge University Press, 1999), 1-50.

3 The economic aspects of Southeast Asia as a regional unit until the later part of the seventeenth century have been studied at length by Anthony Reid, Southeast Asia in the Age of Commerce 1450-1680: The Lands below the Winds, Vol. 1 (New Haven, CT: Yale University Press, 1988) and Southeast Asia in the Age of Commerce 1450-1680: Expansion and Crisis, vol. 2 (New Haven, CT: Yale University Press, 1988). For the commercial activities between China and Southeast Asia, see Eric Tagliacozzo and Wen-Chin Chang, eds., Chinese Circulations: Capital. Commodities, and Networks in Southeast Asia (Durham, NC: Duke University Press, 2011).

${ }^{4}$ See Thomas David DuBois, Religion and the Making of Modern East Asia (Cambridge: Cambridge University Press, 2011), 1-14. 


\section{The Current State of Southeast Asian Christianity}

East (Northeast) and Southeast Asia as a whole, in distinction from Central, West, and South Asia, are the most religiously diverse regions in the world. In 2020, the percentages of adherents of the main religions in these two regions are as follows: Buddhists (22\%), Chinese folk-religionists (20\%), Christians $(12 \%)$, Muslims $(12 \%)$, and agnostics $(22 \%){ }^{5}$

In Southeast Asia, Islam is the largest religion, with the world's largest Muslim population in Indonesia (217 million) and Malaysia (18 million). It is the state religion of Malaysia and Brunei. Buddhism is the second-largest religion. In Burma, $89 \%$ of the population practice Buddhism, in Thailand $93 \%$, in Laos $67 \%$, in Vietnam 16.4\%, and in Cambodia 97\%. Hinduism has about $2 \%$ of the Southeast Asian population, with a significant presence in Indonesia (Bali) and Malaysia. However, the fastest-growing religion between 1970 and 2020 is Christianity, at an average of $2.2 \%$ per year. ${ }^{6}$ Every statistical report of Southeast Asian Christianity invariably begins with the affirmation that Christianity is a minority religion in Asia and then immediately qualifies it with the exception of the Philippines and Timor-Leste, two predominantly Catholic countries in Asia. Also, the growth of Christianity in East and Southeast Asia in the last fifty years (19702020) has been phenomenal, at $3.1 \%$ per year. ${ }^{7}$

In 2020, the total number of Christians in Southeast Asia is 153 million (23\% of the population), up from 51 million in 1970. Most Southeast Asian Christians are Catholic $(67 \%$ of all Christians) thanks to the large number of Filipino Catholics. The percentage of Christians in the populations of Southeast Asian countries are as follows: Myanmar (8\%), Laos (3\%), Thailand (1\%), Cambodia (3\%), Vietnam (9\%), the Philippines (91\%), Singapore (20\%), Malaysia (9\%), Brunei (12\%), Indonesia (12\%), and TimorLeste $(89 \%)$. Besides Catholicism, other Christian denominations

${ }^{5}$ Gina A. Zurlo, "A Demographic Profile of Christanity in East and Southeast Asia," in Christianity in East and Southeast Asia, eds., Kenneth Ross, Francis D. Alvarez, and Todd M. Johnson (Edinburgh: University of Edinburgh Press, 2020).

${ }^{6}$ Ibid., 13.

${ }^{7}$ For statistical information and general studies on Asian Christianity, the following are indispensable: David B. Barrett and Todd M. Johnson, World Christian Trends AD 30-AD 2200 (Pasadena, CA: William Carey Library, 2001); Todd M. Johnson and Kenneth Ross, eds., Atlas of Global Christianity 1910-2010 (Edinburgh: University of Edinburgh Press, 2009); Patrick Johnstone, The Future of the Global Church: History, Trends and Possibilities (Downers Grove, IL: InterVarsity Press, 2011); Todd M. Johnson and Gina A. Zurlo, eds., World Christian Encyclopedia, $3^{\text {rd }}$ ed. (Edinburgh: Edinburgh University Press, 2020); the online World Christian Database (Brill); Kenneth R. Ross, Francis D. Alvarez, and Todd M. Johnson, eds., Christianity in East and Southeast Asia (Edinburgh: University of Edinburgh Press, 2020). 
are also present in Southeast Asia, including Anglicanism, Orthodoxy, Protestantism, Evangelicalism, Pentecostal/Charismatic Christianity, and Independents. ${ }^{8}$

It is projected that by 2050 the number of Christians in East and Southeast Asia will likely grow to 430 million (18\% of the population), up from 282 million in 2020, with Independents and Evangelicals/Charismatics likely outpacing Catholics and Protestants.

\section{Common Issues Facing Southeast Asian Christianity}

Just as Southeast Asia, despite the mind-boggling sociopolitical, linguistic, cultural, and religious diversity of its constituent nation-states, can be fruitfully studied as a regional whole, Southeast Asian Christianity, albeit quite varied from country to country, possesses significant common features and problems that permit an overview that is useful for understanding the challenges and opportunities facing Southeast Asian Christianity.

First, it has often been said that in Southeast Asia Christianity was and still remains a foreign religion that was imported by Western missionaries. Historically, this is true of Christianity in all the eleven Southeast Asian nations. Christianity was brought to Southeast Asia from the late sixteenth century by missionaries from Portugal (Vietnam and Timor-Leste), Spain (the Philippines), the Netherlands (Indonesia), Britain (Malaysia and Singapore), France (Vietnam, Cambodia, Laos, and Thailand), and the United States (Myanmar and the Philippines). However, "foreignness" cannot be said of Christianity alone as it is also true of Hinduism, Buddhism, Daoism, Confucianism, and Islam, which were brought to Southeast Asia from India, China, and the Middle East. Perhaps the point of the observation about the foreign character of Christianity is that Christianity has not been thoroughly indigenized into the local cultures and contexts like the other religions and that some Christian denominations are currently still dependent on foreign financial aid and administrative authorities, not subscribing to the Three-Self Principles, namely, self-governing, self-supporting, and self-propagating. ' This is Asia," 12-13.

${ }^{8}$ Zurlo, "A Demographic Profile of Christanity in East and Southeast

9 The three principles of self-governance, self-support, and selfpropagation were first articulated by Henry Venn, General Secretary of the Church Missionary Society from 1841 to 1873, and Rufus Anderson, Foreign Secretary of the American Board of Commissioners for Foreign Missions. The three-self principle is also known as the "Nevius Method," named for John Livingstone Nevius, a missionary to China and Korea, who developed the threeself principle into a plan for establishing indigenous churches. By 1877 the threeself principle was much discussed among Protestant missionaries to China. Today, the principle is associated with the Protestant Three-Self Patriotic Movement and the Chinese Patriotic Catholic Association. I have suggested that 
especially true of the Catholic Church, with its organizational and juridical ties to the Vatican City State.

As valid as this criticism is, it must be acknowledged that recently Christian Churches in Southeast Asia have been seriously engaged in what is termed "inculturation." While Protestants, Evangelicals, and Pentecostals devote their resources to translating the Bible into hundreds of local languages, Catholics and Anglicans focus on adapting the liturgy and worship to the local cultures, making use of indigenous music, song, dance, rituals, practices of popular religion, and customs. ${ }^{10}$ In the Catholic Church, the Federation of Asian Bishops' Conferences (FABC) has repeatedly insisted on the need for inculturation in all aspects of the Christian life, ${ }^{11}$ and the Christian Conference of Asia (CCA) has advocated contextualization for Protestant, Evangelical, and Pentecostal Churches. ${ }^{12}$

Secondly, connected with the foreignness of Christianity is the historical alliance between Christianity and colonialism in Southeast Asia. As mentioned above, missionaries from Portugal, Spain, Britain, France, and the United States came to evangelize Southeast Asian countries with the financial and political support of their colonizing countries. A notable example of the collusion between secular power and Church authorities is the system of royal patronage instituted in the fifteenth century between the

a fourth principle, namely, self-theologizing should be added to the plan of developing an indigenous theology in Asia.

10 A religious practice that has caused much controversy in Asia is the cult of ancestors or ancestor veneration/worship. The so-called "Chinese Rites Controversy," as the name implies, started in China in the second part of the seventeenth century but it impacted also Catholic missions in Sinicized countries in Southeast Asia such as Vietnam, Malaysia, and Singapore. The question was whether these rituals, which were rendered to Confucius and the dead, are superstition or merely civil acts of gratitude and honor to Confucius and the ancestors. The Dominicans and the members of the Société des Missions Étrangères de Paris opted for the former and the Jesuits for the latter. Several popes condemned these rituals and forbade missionaries to tolerate them under pain of excommunication and did not approve them until 1939 under Pope Pius XII.

11 The FABC was founded in 1972. For a collection of the FABC's and its various Offices' documents, see Gaudencio Rosales and C. G. Arévalo, eds., For All Peoples of Asia: Federation of Asian Bishops' Conferences. Documents from 1970 to 1991, Vol. 1 (Maryknoll, NY: Orbis Books, 1991); Franz-Josef Eilers, ed., For All the Peoples of Asia: Federation of Asian Bishops' Conferences. Documents from 1992 to 1996, Vol. 3 (Quezon City, Philippines: Claretian Publications, 1997); FranzJosef Eilers, ed., For All the Peoples of Asia: Federation of Asian Bishops' Conferences. Documents from 1997 to 2001, Vol. 3 (Quezon City, Philippines: Claretian Publications, 2002); Franz-Josef Eilers, ed., For All the Peoples of Asia: Federation of Asian Bishops' Conferences. Documents from 2002 to 2006, Vol. 4 (Quezon City, Philippines: Claretian Publications, 2007); Vimal Tirimanna, ed., For All the Peoples of Asia: Federation of Asian Bishops' Conferences. Documents from 2007 to 2012, Vol. 5 (Quezon City, Philippines: Claretian Publications, 2013).

${ }^{12}$ On the CCA, see its official website https://cca.org.hk. 
Catholic Church on the one hand and Spain (patronato real) and Portugal (padroado real) on the other whereby in exchange for the free use of transportation to mission countries, financial subsidy for the building of churches and the maintenance of missionaries, and military protection for Christian missions, the two royal Crowns would have the privilege to appoint candidates for the episcopacy and other high ecclesiastical offices in their newly discovered and conquered territories in Latin America and Asia. No doubt the Catholic Church benefited much from this arrangement; indeed, without the assistance of the Iberian empires, it was very unlikely that the Church could have carried out its evangelizing mission in the new worlds of Latin America and Asia.

However, this patronato/padroado real system unavoidably produced a constant intermingling of conflicting interests in commerce, politics, and religion in which the credibility of the Gospel was severely compromised. Catholic missions in Asia in the seventeenth century suffered greatly as the spiritual harms of royal patronage far outweighed the material benefits, especially after Portugal had lost its territories and trade to the Netherlands whose Dutch United East India Company (Vereenigde Oost-Indische Compagnie) overtook the Portuguese in commerce all over Asia. To remove its dependence on the Iberian monarchies, the Catholic Church established the Sacred Congregation for the Propagation of the Faith (Congregatio de Propaganda Fide) in 1622. Thereafter, missionaries would receive their mandate from Rome rather than Madrid and Lisbon; apostolic vicars (bishops of territories having no ordinary hierarchy) and prefects (having episcopal powers, but not necessarily bishops) would be appointed by the Congregation bypassing the obligatory approval of the Portuguese and Spanish monarchs. ${ }^{13}$ Other Christian Churches have also benefited from

${ }^{13}$ Here the focus is on the Portuguese and Spanish royal patronage in Southeast Asia. The impact of the Portuguese padroado real was much greater in India, particularly in the archdiocese of Goa, marked by jurisdictional disputes between the padroado clergy and that of the Propaganda. The Portuguese padroado in India covered the archdiocese of Goa and the dioceses of Damão, Cranganor, Cochin, and Mylapore. The diocese of Bombay (Mumbai) remained under the double jurisdiction of the padroado and the Propaganda. Subsequent agreements between the Holy See and Portugal reduced the field of the padroado missions. In 1950, after the independence of India and upon negotiations with the Holy See, Portugal renounced the padroado in India, except the archdiocese of Goa which kept some mission posts outside Portuguese Goa. A final agreement, signed on Oct. 25, 1953, put an end to the padroado in India. In 1974, the Portuguese renounced their padroado privileges over the diocese of Macau, putting an end to the padroado system. In Africa and in Brazil, the padroado system posed no difficulties since Propaganda missionaries did not try to work in those territories. In Southeast Asia, only the Philippines was under the Spanish patronato. The Spaniards established a colonial government in the Philippines with the support of the Spanish Crown and the Church. The Filipino Church was placed under the authority of the Spanish King, and was administered by the Supreme Council 
their colonizing countries, though not by means of contractual obligations of the royal-patronage type and to a much lesser extent. Reformed Christianity in Indonesia benefited from the Netherlands; the Catholic Church in Vietnam, Cambodia, and Laos from France; the Baptist Church in Myanmar from the United States; and the Anglican Church in Brunei, Malaysia, and Singapore from Britain. Only Thailand escaped the colonization by Western powers.

Christians in Southeast Asia must honestly acknowledge the colonial legacy of their Churches and the many privileges accrued to them, especially in terms of education, health care, and social services, as the best schools, universities, hospitals, and social institutions in their countries are owned or administered by Christians. Furthermore, while globalization has raised the living standards in several Southeast Asian countries, its neoliberal market economy has widened the gap between the rich and the poor. In this context, Southeast Asian Christians must denounce this new form of colonialism that is no less destructive of their human dignity and rights than the old one. Neocolonialism is all the more dangerous as its impact is not as visible as the colonizers' occupation of their lands and exploitation of their natural resources. Furthermore, one of the most pernicious effects of the neoliberal economy is consumerism, which is the siren's song to youth and enslaves the consumers as they accumulate more and more things.

The third common feature of Southeast Asian countries is overwhelming poverty. While Singapore is one of the four economic "Asian Tigers" (the others being in East Asia, namely, South Korea, Taiwan, and Hong Kong) thanks to their rapid economic growth and an improved standard of living, and though Indonesia, Malaysia, Thailand, and Vietnam have recently reached the status of economic "Tiger Cubs," there are still millions of Southeast Asians living below poverty level, subsisting on less than US\$ 1.90 a day and having little access to education, health care, and social services. This extreme poverty is exacerbated by more frequent and more severe natural disasters, some related to climate change, such as drought, tsunami, flood, and earthquake, that destroy the poor's livelihood and force them to migrate. Furthermore, massive poverty is also worsened by the endemic corruption and graft by kleptocratic governments that steal public funds from public projects earmarked for the betterment of the living standards in their countries. In defense of the exploited poor, the FABC repeatedly advocates the "dialogue with the poor,"

of the Indies and the Viceroy of New Spain. The patronage system was ended when the United States took the Philippines away from Spain at the conclusion of the Spanish-American War in 1898.

Peter C. Phan: https://doi.org/10.46567/ijt.v9i1.209 
which consists of the Church's "option for the poor" and solidarity with them to achieve their liberation from structural injustice and oppression. In this struggle for social justice, the poor themselves act as agents of their liberation and are not just victims and beneficiaries of the charity of others.

The fourth common feature of Southeast Asian countries is ubiquitous migration. In the last fifty years, Asia has massively entered the global migration age. Rapid economic growth, the impact of globalization, social transformations, international and civil wars, and ecological disasters have accelerated the rate of migration of Asians from Asian countries to non-Asian countries, to other Asian countries, and also within each country. From the end of World War II and the dismantling of British, French, Dutch, and Japanese colonial empires to 1973, there were waves of returning colonists, often with their families of colonial subjects, to their respective countries, especially from Indonesia to Holland, from Vietnam to France, and from Timor-Leste to Portugal. Also during these three decades, there were protracted wars in Korea and Vietnam that caused millions of people to leave the north for the south. During 1975-1989, after the Oil Boom, the Gulf region emerged as the new migration destination for Asian migrants, especially from India, Pakistan, and the Philippines. The end of the Vietnam War, with the victory of Communist North Vietnam over South Vietnam in 1975, saw hundreds of thousands of Vietnamese, Cambodians, and Laotians migrate to the U.S., Canada, Australia, and European countries. During 1989-2008, the increasing demand for lower-and higher-skilled workers in the Gulf region attracted more Southeast Asian migrants. Also, there was intra-regional migration from poorer Southeast Asian countries like Indonesia, Vietnam, and the Philippines to richer Southeast Asian countries like Malaysia, Singapore, and Thailand and to East Asian countries such as Japan, South Korea, and Taiwan. Since 2008 there has been an acceleration of extra-regional migration, especially from Indonesia and Myanmar, to the Gulf, North America, and Europe, and intra-regional migration, especially to East Asia and some countries of Southeast Asia. Recently there has been a forced displacement of Rohyngis from Myanmar and Uyghurs in Northwest China.

Several aspects of Southeast Asian migration, voluntary and forced, are worth noting. First, one of the results of military conflicts during the Cold War and the post-Cold War era is refugee migration, as in the cases of Korea, Vietnam, and Sri Lanka. Second, there is the labor contract migration in response to the need for workers in industrially developed countries such as Japan, South Korea, China, Thailand, the Gulf region, the U.S, and Europe. Most of these migrants are low-skilled workers hired for the so-called 3D jobs (dangerous, difficult, and dirty) such as 
farming, road repairs, construction, catering, and driving. A smaller number are high-skilled professionals, especially in the fields of IT and healthcare, benefiting from the "global race for talent." The emigration of the highly educated class has caused the "brain drain" in their countries which need their talents for local development. Third, there is the globalization of domestic work and the feminization of migration. As the birth rate falls in richer countries and as many women pursue careers, there is a need for migrant women to fill "typically female" jobs, such as domestic work, child care, restaurant and hotel staff, entertainment (a euphemism for prostitution), assembly-line work in clothing and electronic, and other low-paid menial work. Fourth, there is marriage migration, which in early times provided "war brides" and "mail-order" brides to the U.S. and Europe but today answers the need for wives in countries with very low fertility rate (e.g., Japan and South Korea), with a preference for male children (e.g., China and India), or with the one-child policy (e.g., China). Since the 1990s, marriage migration was the major driver of intra-Asian migration. Fifthly, Asian countries that have become migration destinations, in East Asia such as Japan, South Korea, China, Hong Kong, and Taiwan, and Southeast Asia such as Malaysia, Singapore, Brunei, and Thailand, have labor contracts to import workers from other Asian countries but only for a fixed number of years. They are very reluctant to grant migrant workers permanent residency, much less citizenship, for fear of diluting their alleged racial homogeneity and national identity. Finally, migrants, whatever income they receive from work abroad, are expected to send money home to help the members of their families that remain behind. These remittances from migrants, which reached 442 US $\$$ billion in 2017, constitute a great part of the GDP of some countries, for example, India $(62.5 \%)$ and the Philippines (25.7). The fact that remittances provide countries of origin with a political-economic "safety valve" and hard currency explains why their governments have little incentive to reduce emigration. ${ }^{14}$

The Philippines is arguably the prime example of migration as described above. The country is said to possess a national "culture of emigration," making going abroad to work and live a normal expectation of many Filipinos. A nationwide survey of 1,200 adult respondents in 2002 found one in five Filipinos expressing a desire to migrate. After the Second World War, the Philippines evolved into a major emigration country, and labor export has been an official policy since the 1970s. Its government

${ }^{14}$ For a detailed discussion of migration in Southeast Asia, see Hein De Haas, Stephen Castles, and Mark J. Miller, The Age of Migration: International Population Movements in the Modern World, $6^{\text {th }}$ ed. (New York: Guilford Press, 2020), 173-190. On remittances, see Haas, Castles, and Miller, The Age of Migration, 331352.

Peter C. Phan: https://doi.org/10.46567/ijt.v9i1.209 
has developed institutions to manage labor export such as the Philippines Overseas Employment Administration and to maintain links with the diaspora such as the Commission on Filipinos Overseas. According to Filipino authorities, in 2013, about 10.2 million or more than 10 percent of the Filipino population worked abroad. The destination country of choice is the U.S., but Filipino migrants are found in close to 200 countries and territories around the world. As for the feminization of migration, the female share among first-time migrant workers from the Philippines rose from 50 percent in 1992 to 72 percent in 2006. There is also marriage migration, especially to South Korea and Japan. While the majority of Filipino migrants are low-skilled workers, a good number of them are high-skilled. In the 1980s-1990s, about 40 percent of Filipino permanent emigrants had a college degree, and 30 percent of IT workers and 60 percent of doctors of the country emigrated. The Philippines deliberately trained surplus medical personnel such as nurses with the explicit goal of exporting this labor force. There is thus a significant "brain drain" in the Philippines; conversely, the remittances, as mentioned above, are sizeable.

The fifth and last common feature of Christianity is its minority status in all Southeast Asian countries, except the Philippines and Timor-Leste. In 2020, Southeast Asia was 23\% Christian (153 million of the total population of more than 655 million). This minority status-in terms of number and not necessarily in social influence-requires Christians to learn how to live their faith in non-Christian majority countries and in countries where religious freedom is severely curtailed. In self-declared Communist countries, namely, China, Vietnam, Laos, and North Korea, Christianity is not targeted for eradication but Churches must be registered and their activities regulated and restricted under the pretext of "national security" and "social unity." In authoritarian countries, often under military regimes, such as Cambodia and Myanmar, religious repression and violations of other human rights are committed not in the name of ideology but to maintain absolute power. In Muslim-majority countries such as Brunei, Indonesia, and Malaysia, in principle, religious freedom is constitutionally guaranteed, but in practice, legal restrictions on religious practices are put in place, especially when right-wing movements are in power. Of special concern are the blasphemy law and the prohibitions against conversion from Islam, the use of the term Allah, the distribution of bibles, missionary activities, and public celebration of Christian feasts. ${ }^{15}$

15 On religious freedom in East and Southeast Asia, see Paul Marshall, "Religious Freedom," in Christianity in East and Southeast Asia, eds., Kenneth Ross, Francis D. Alvarez, and Todd M. Johnson (Edinburgh: Edinburgh University Press, 2020), 12-13. 


\section{Future Challenges and Opportunities for Southeast Asian Christianity}

The five essays in this issue of the Indonesian Journal of Theology investigate specific problems facing Southeast Asian Christianity such as postcolonialism, liberation theology, nationalism, the theology of food and Holy Communion, and the role of women. In various ways, directly or indirectly, they deal with current and future challenges as well as opportunities facing Christianity in Southeast Asia. In the last part of my Introduction, I would like to highlight the most urgent of these for consideration. ${ }^{16}$

First, the widespread and dehumanizing poverty in several Southeast Asian countries, except Singapore, Malaysia, and Brunei, must be the constant concern of Southeast Asian Churches. This poverty has been exacerbated by neocolonialist globalization, government corruption, anti-democratic militaristic regime, increasing urbanization, and ecological disasters, which prevent social, political, and economic projects from attaining their goals of bringing about the well-being of the most marginalized citizens. The work of abolishing poverty is known as liberation or integral human development. ${ }^{17}$

Second, connected with poverty is the issue of migration. Several Southeast Asian countries are countries of emigration, especially the Philippines, Vietnam, Indonesia, and Myanmar. Churches must set up programs to prepare emigrants before their departure, connect with them while they are abroad, and assist the families that are left behind. Emigration cannot be eliminated, but efforts must be made by both the government and the Churches to reduce the "culture of emigration," the feminization of labor export, sex trafficking, and the misuse of remittances in the emigration countries. ${ }^{18}$

Third, the work to make Christianity a truly Asian religion through comprehensive inculturation or contextualization, already well underway in several countries, should be assiduously continued and expanded to all aspects of the church life. ${ }^{19}$ Here

${ }^{16}$ For a summary of the issues facing Christianity in Southeast Asia, see Mary Ho, "The Future of Christianity in East and Southeast Asia," in Christianity in East and Southeast Asia, eds., Kenneth Ross, Francis D. Alvarez, and Todd M. Johnson (Edinburgh: Edinburgh University Press, 2020), 479-492.

17 On this issue, see C. H. Kim, "Social and Political Context," in Christianity in East and Southeast Asia, eds., Kenneth Ross, Francis D. Alvarez, and Todd M. Johnson (Edinburgh: Edinburgh University Press, 2020), 387-399.

18 On migration, see Maruja M. B. Asis, "Migration," in Christianity in East and Southeast Asia, eds., Kenneth R. Ross, Francis D. Alvarez, and Todd M. Johnson (Edinburgh: Edinburgh University Press, 2020), 451-462.

19 On inculturation, see José Mario C. Francisco, "Faith and Culture," in Christianity in East and Southeast Asia, eds., Kenneth R. Ross, Francis D. 
theology has an irreplaceable role. ${ }^{20}$ Beyond classical resources such as philosophy and religion, such theological inculturation must take into account the socio-political and economic contexts, cultural artifacts, and digital social media. In this way, Southeast Asian Christianity can effectively shed its colonial heritage and its foreign character.

Fourth, interreligious dialogue must be seriously undertaken in Christian-majority as well as Christian-minority countries in four areas, as frequently advocated by the FABC, namely, sharing daily life, collaboration for the common good, theological reflection, and sharing spiritual experiences. This interreligious dialogue not only promotes a deeper understanding and acceptance of the religious "Other" but is also an effective means to reduce religious extremism, radicalism, and violence in Asia. $^{21}$

Fifth, related to the issues of liberation, inculturation, and interreligious dialogue is the nature of Christian mission. Mission or evangelism is understood and practiced very differently by Christians in Southeast Asia. Evangelicals, Pentecostals/Charismatics, and Independents understand mission as consisting mainly in preaching to non-Christians with the ultimate goal of converting and baptizing them and, as we have seen above, this kind of mission is prohibited in some Muslimmajority Southeast Asian countries. On the other hand, other Churches understand mission as bearing witness, by word and deed, to the Christian faith with the goal not primarily to convert non-Christian individuals, though this is not excluded, but to bring the reality and values of God's reign/kingdom to the world. The mode of doing so is a sincere, humble, and respectful dialogue with non-Christians, in the four areas listed above: life, work, reflection, and spirituality. This fourfold dialogue does not replace mission but is the way or mode in which mission should be carried out. This fundamental difference in the understanding and practice of mission among Christian Churches in Southeast Asia must be honestly faced, for which ecumenical dialogue is essential.

Both Christianity, especially in its Pentecostal/Charismatic branch, and Islam are predicted to enjoy significant growth in Southeast Asia in the next 25 years. Both religions and their mutual

Alvarez, and Todd M. Johnson (Edinburgh: Edinburgh University Press, 2020), 351-363.

${ }^{20}$ On theology, see Alexander Chow, "Theology," in Christianity in East and Southeast Asia, eds., Kenneth R. Ross, Francis D. Alvarez, and Todd M. Johnson (Edinburgh: Edinburgh University Press, 2020), 375-386.

${ }^{21}$ On interreligious dialogue, see Sivin Kit, "Inter-Religious Relation," in Christianity in East and Southeast Asia, eds., Kenneth R. Ross, Francis D. Alvarez, and Todd M. Johnson (Edinburgh: Edinburgh University Press, 2020), 438-450.

Indonesian Journal of Theology, Vol. 9, No. 1 
encounters are fraught with challenges; by the same token, they are also presented with opportunities. Whether Southeast Asia will flourish in peace and prosperity or regress to violence and backwardness in the near future depends largely on how they meet the challenges and take advantage of the opportunities.

\section{About the Author}

Peter C. Phan, who has earned three doctorates, is the inaugural holder of the Ignacio Ellacuría Chair of Catholic Social Thought at Georgetown University, USA. His research deals with the theology of icon in Orthodox theology, patristic theology, eschatology, the history of Christian missions in Asia, liberation, inculturation, and interreligious dialogue. He is the author and editor of over 30 books and has published over 300 essays. His writings have been translated into Arabic, French, German, Italian, Polish, Portuguese, Romanian, Serbian, Spanish, Chinese, Indonesian, Japanese, and Vietnamese, and have received many awards from learned societies. He is the first non-Anglo to be elected President of Catholic Theological Society of America and President of American Theological Society. In 2010 he received the John Courtney Murray Award, the highest honor bestowed by the Catholic Theological Society of America for outstanding achievement in theology. He has also been awarded four honorary doctorates.

\section{Bibliography}

Asis, Maruja M. B. "Migration.” In Christianity in East and Southeast Asia. Eds., Kenneth R. Ross, Francis D. Alvarez, and Todd M. Johnson. Edinburgh: Edinburgh University Press, 2020.

Barrett, David B., and Todd M. Johnson. World Christian Trends AD 30-AD 2200. Pasadena, CA: William Carey Library, 2001.

Chow, Alexander. "Theology." In Christianity in East and Southeast Asia. Eds., Kenneth R. Ross, Francis D. Alvarez, and Todd M. Johnson. Edinburgh: Edinburgh University Press, 2020.

D. R. SarDesai. Southeast Asia: Past \& Present. Boulder, CO: Westview Press, 1994.

DuBois, Thomas David. Religion and the Making of Modern East Asia. Cambridge: Cambridge University Press, 2011.

Eilers, Franz-Josef, ed. For All the Peoples of Asia: Federation of Asian Bishops' Conferences. Documents from 1992 to 1996. Vol. 3. Quezon City, Philippines: Claretian Publications, 1997. ed. For All the Peoples of Asia: Federation of Asian Bishops' Conferences. Documents from 1997 to 2001. Vol. 3. Quezon City, Philippines: Claretian Publications, 2002. ed. For All the Peoples of Asia: Federation of Asian Bishops' Conferences. Documents from 2002 to 2006. Vol. 4. Quezon City, 
Philippines: Claretian Publications, 2007.

Francisco, José Mario C. "Faith and Culture." In Christianity in East and Southeast Asia. Eds., Kenneth R. Ross, Francis D. Alvarez, and Todd M. Johnson. Edinburgh: Edinburgh University Press, 2020.

Gin, Ooi Keat. Southeast Asia: A Historical Encyclopedia from Angkor Wat to East Timor. Santa Barbara, CA: ABC Clio, 2004.

Haas, Hein De, Stephen Castles, and Mark J. Miller. The Age of Migration: International Population Movements in the Modern World. $6^{\text {th }}$ ed. New York: Guilford Press, 2020.

Ho, Mary. "The Future of Christianity in East and Southeast Asia." In Christianity in East and Southeast Asia. Eds., Kenneth Ross, Francis D. Alvarez, and Todd M. Johnson. Edinburgh: Edinburgh University Press, 2020.

Johnson, Todd M., and Kenneth Ross, eds. Atlas of Global Christianity 1910-2010. Edinburgh: University of Edinburgh Press, 2009.

Johnson, Todd M., and Gina A. Zurlo, eds. World Christian Encyclopedia. $3^{\text {rd }}$ ed. Edinburgh: Edinburgh University Press, 2020.

Johnstone, Patrick. The Future of the Global Church: History, Trends and Possibilities. Downers Grove, IL: InterVarsity Press, 2011.

Kim, C. H. "Social and Political Context." In Christianity in East and Southeast Asia. Eds., Kenneth Ross, Francis D. Alvarez, and Todd M. Johnson. Edinburgh: Edinburgh University Press, 2020.

Kit, Sivin. "Inter-Religious Relation." In Christianity in East and Southeast Asia. Eds., Kenneth R. Ross, Francis D. Alvarez, and Todd M. Johnson. Edinburgh: Edinburgh University Press, 2020.

Legge, J. D. "The Writing of Southeast Asian History." In The Cambridge History of Southeast Asia, Volume One: From Early Times to c. 1500. Ed., Nicholas Tarling. Cambridge: Cambridge University Press, 1999.

Marshall, Paul. "Religious Freedom." In Christianity in East and Southeast Asia. Eds., Kenneth Ross, Francis D. Alvarez, and Todd M. Johnson. Edinburgh: Edinburgh University Press, 2020.

Nicholas Tarling, ed. The Cambridge History of Southeast Asia. Cambridge: Cambridge University Press, 1999.

Osborne, Milton. Exploring Southeast Asia: A Traveler's History of the Region. Crows Nest, Australia: Allen \& Unwin, 2002.

. Southeast Asia: An Introductory History. Crows Nest, Australia: Allen Unwin, 2016.

Owen, Norman G., ed. The Emergence of Modern Southeast Asia: A New History. Honolulu, HI: University of Hawai'i Press, 2005.

Reid, Anthony. Southeast Asia in the Age of Commerce 1450-1680: 
Expansion and Crisis. Vol. 2. New Haven, CT: Yale University Press, 1988.

Southeast Asia in the Age of Commerce 1450-1680: The Lands below the Winds. Vol. 1. New Haven, CT: Yale University Press, 1988.

Rosales, Gaudencio, and C. G. Arévalo, eds. For All Peoples of Asia: Federation of Asian Bishops' Conferences. Documents from 1970 to 1991. Vol. 1. Maryknoll, NY: Orbis Books, 1991.

Ross, Kenneth R., Francis D. Alvarez, and Todd M. Johnson, eds. Christianity in East and Southeast Asia. Edinburgh: University of Edinburgh Press, 2020.

Tagliacozzo, Eric, and Wen-Chin Chang, eds. Chinese Circulations: Capital. Commodities, and Networks in Southeast Asia. Durham, NC: Duke University Press, 2011.

Tirimanna, Vimal, ed. For All the Peoples of Asia: Federation of Asian Bishops' Conferences. Documents from 2007 to 2012. Vol. 5. Quezon City, Philippines: Claretian Publications, 2013.

Winzeler, Robert L. The Peoples of Southeast Asia Today: Ethnography, Ethnology, and Change in a Complex Region. Lanham, MD: Rowman \& Littlefield, 2011.

Wolters, Oliver W. History, Culture, and Region in Southeast Asian Perspectives. Ithaca, NY: SEAP, 1999.

Zurlo, Gina A. "A Demographic Profile of Christanity in East and Southeast Asia." In Christianity in East and Southeast Asia. Eds., Kenneth Ross, Francis D. Alvarez, and Todd M. Johnson. Edinburgh: University of Edinburgh Press, 2020. 